\title{
Determination of Grapevine Leafroll Diseases Infection in Turkey
}

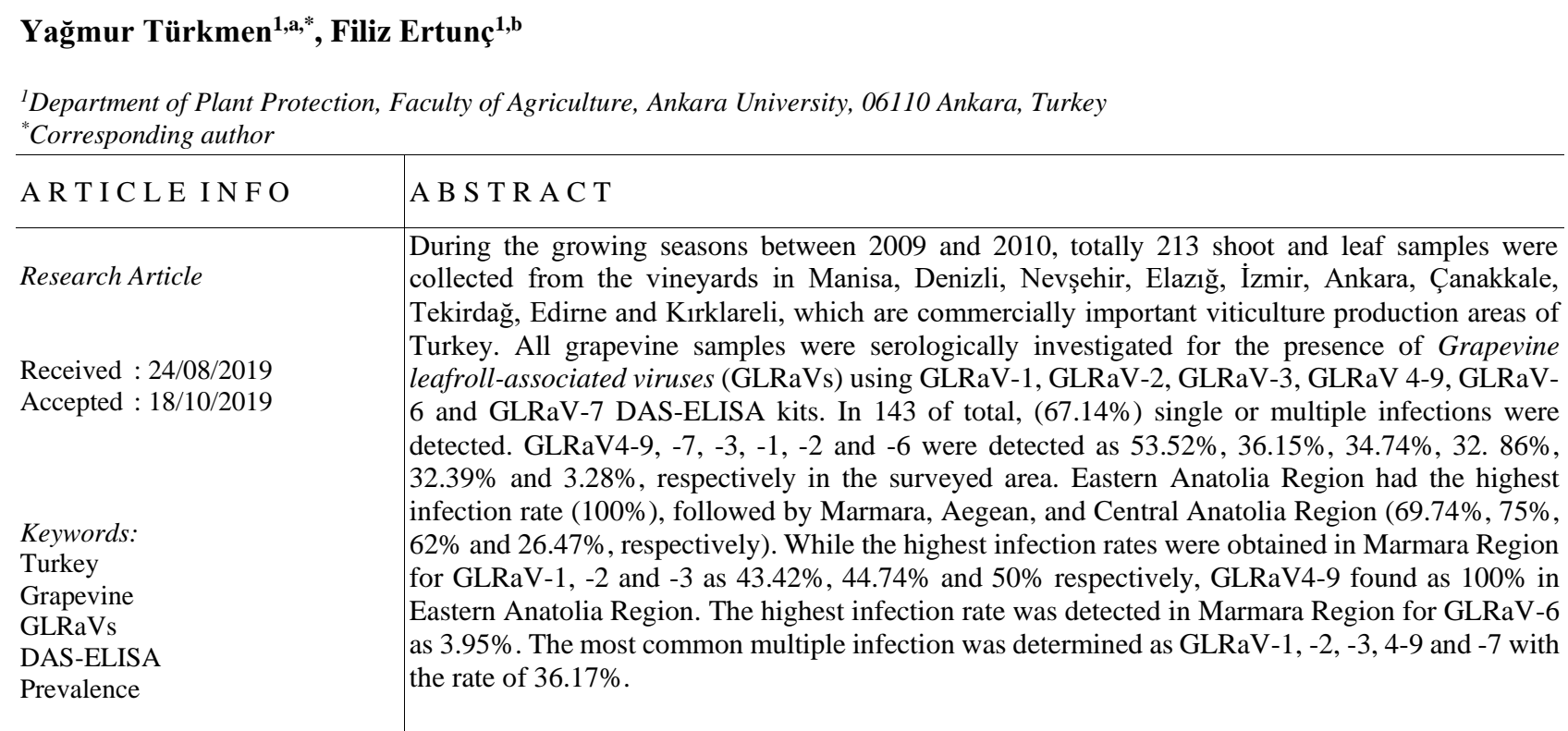

\section{Introduction}

As a consequence of being located in the center of the domesticated area of Vitis vinifera, Turkey serves as a great gene source for both cultivated (Vitis vinifera ssp. sativa) and wild grapevine (Vitis vinifera ssp. sylvestris) (Söylemezoğlu et al., 2015). Turkey has 416907 ha of grapevine growing area, which is ranked fourth only after Spain, France and Italy, and yielded 4,200 million tons, ranked sixth after other major grapevine producers such as China, Italy, USA, France and Spain (Anonymous, 2017).

Viral diseases constitute a major threat to grapevine production all around the world. Within the numerous virus diseases infecting grapevines, Grapevine Leafroll Disease (GLD) is distinguished as the most intriguing and economically important virus disease in all grapevinecultivated areas around the world (Naidu et al., 2014). GLD appears wherever grapevines are grown and causes a wide range of deleterious impacts such as delay in fruit ripening, reducing yield, altering pigmentation of fruit and reducing sugar accumulation. The most obvious symptom of the disease is leaf reddening in red cultivar and a slight leaf chlorosis in white cultivar. Also, leaf of red and white grapevine cultivars form downward curling (Goheen, 1998). Recently, several distinct GLRaVs, which show differences in genome organization and epidemiology, have been recognized. At present, there are eleven viruses associated with GLD and five of them, specified numerically as GLRaV-1, -2, -3, -4, and -7, are reported as different species and GLRaV-5, -6, -9, -Pr, Car and -De as strains of GLRaV-4 (Martelli et al., 2012). The viruses associated with GLD belong to the family Closteroviridae and GLRaV-2 is classified in the genus Closterovirus, GLRaV 1, -3, and -4 in the genus Ampelovirus, and GLRaV-7 in the recently identified genus Velarivirus (Naidu et al., 2014). Original disperse of GLRaVs appears during the constitution of new vineyards with virusinfected, non-certified propagating material. Secondary spread often occurs through the transmission by scale insect and mealybug vectors (Tsai et al., 2010).

In this study, surveys were performed during the growing seasons between 2009 and 2010 in ten different grapevine cultivated provinces in Aegean, Marmara, Central and Eastern Anatolia Regions, and then the collected samples were analysed by favor of double antibody sandwich enzyme-linked immunosorbent assay (DAS- ELISA). 


\section{Material and Methods}

The surveys were conducted in the late summer (JuneAugust) of 2009-2010 in the primary grapevine growing areas in Aegean, Thrace, Marmara, Central Anatolia and Eastern Anatolia Regions of Turkey including Denizli, Çanakkale, Tekirdağ, Kırklareli, İzmir, Manisa, Edirne, Ankara, Nevşehir and Elazı̆g (Figure 1). Totally 213 symptomatic and non-symptomatic samples were collected as proportionally to the visited vineyard area during the survey. In symptomatic sampling, mainly, intense reddening restricted with green major veins in the leaves of red varieties and inward curling were observed (Figure 2 and Figure 3).

Homogenized leaf samples were subjected to DASELISA (Clark and Adams, 1977) using the commercial antisera kits (Bioreba, Switzerland) for the existence of GLRaV-1, -2, -3, 4-9, -6 and -7. The reagents of the ELISA kit called GLRaV 4-9 contain a mixture of complementary monoclonal antibodies developed against GLRaV-4, GLRaV-4 strain 5, GLRaV-4 strain 6, GLRaV-4 strain 9 and GLRaV-4 strain Ob (Besse and Gugerli, 2009; Reynard et al., 2015).

\section{Results and Discussion}

143 out of 213 tested samples $(67.14 \%)$ were found to be infected with at least one GLRaV. According to the tested grapevine samples from different locations were revealed that GLRaV4-9 was the most common virus $(53.52 \%)$ in Turkey and all of the provinces surveyed were infected with the virus, followed by GLRaV-7, GLRaV-3, GLRaV-1, GLRaV-2 and GLRaV-6 (36.15\%, 34.74\%, 32. 86\%, $32.39 \%$ and $3.28 \%$, respectively). Maximum percentage of infected samples with GLRaV4-9 were found in Elazı̆g followed by Çanakkale, İzmir, Manisa, Ankara, Edirne, Tekirdağ, Denizli, Kırklareli and Nevşehir in 100\%, 92.3\%, $91.42 \%, 55.55 \%, 53.84 \%, 44.44 \%, 41.66 \%, 30 \%, 5.88 \%$ and $4.76 \%$ respectively. The second most common virus was GLRaV-7 (36.15\%). Occurrence of GLRaV-7 was recorded in İzmir $(77.14 \%)$, Tekirdağ $(50 \%)$, Çanakkale (46.15\%), Elazı̆̆ (45.45\%), Ankara (38.46\%), Denizli (30\%), Kirklareli (23.52\%) and Nevşehir (9.52\%), respectively. However, no sample was found infected with GLRaV-1 (Elazı̆ğ, Nevşehir and Edirne), GLRaV-2 and GLRaV-3 in Edirne and GLRaV-7 (Manisa and Edirne). Whereas, no sample was infected with GLRaV-6 in Denizli, Çanakkale, Kırklareli, Ankara, Elazığ and Edirne. The results obtained from DAS-ELISA showed that 143 $(67.14 \%)$ samples were infected with GLRaVs. A total of 70 $(32.86 \%)$ samples were found non-infected against the tested viruses. Among the tested grapevine maximum and minimum GLRaVs free samples obtained from Nevşehir (85.71\%) and İzmir (2.85\%) respectively (Table 1). The pattern of GLRaVs based on provinces given in Figure 4.

In this study, totally four region where the viticulture intensively performed were surveyed in Turkey. According to results obtained from DAS-ELISA tests, Eastern Anatolia Region had the highest infection rate (100\%), followed by Marmara, Aegean, and Central Anatolia Region $(69.74 \%, 75 \%, 62 \%$ and $26.47 \%$, respectively). Whereas the maximum infection rate was detected in Marmara Region for, GLRaV-1, -2 and -3 as $43.42 \%$,
$44.74 \%$ and $50 \%$, respectively, for GLRaV4-9 this rate was $100 \%$ in Eastern Anatolia Region. The highest infection rates were detected in Marmara Region for GLRaV-6 as $3.95 \%$ (Table 1).

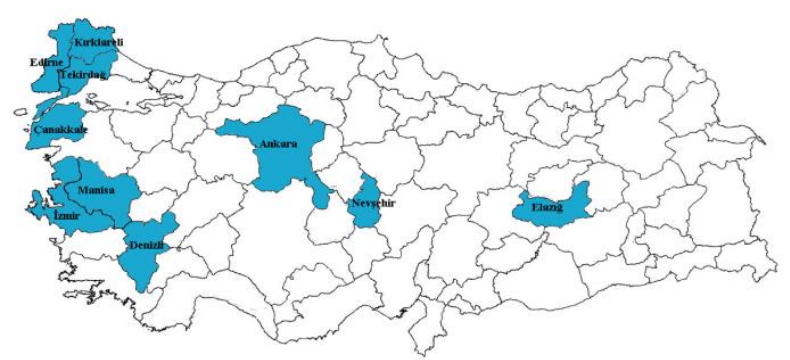

Figure 1 The surveyed grapevine growing areas in Turkey

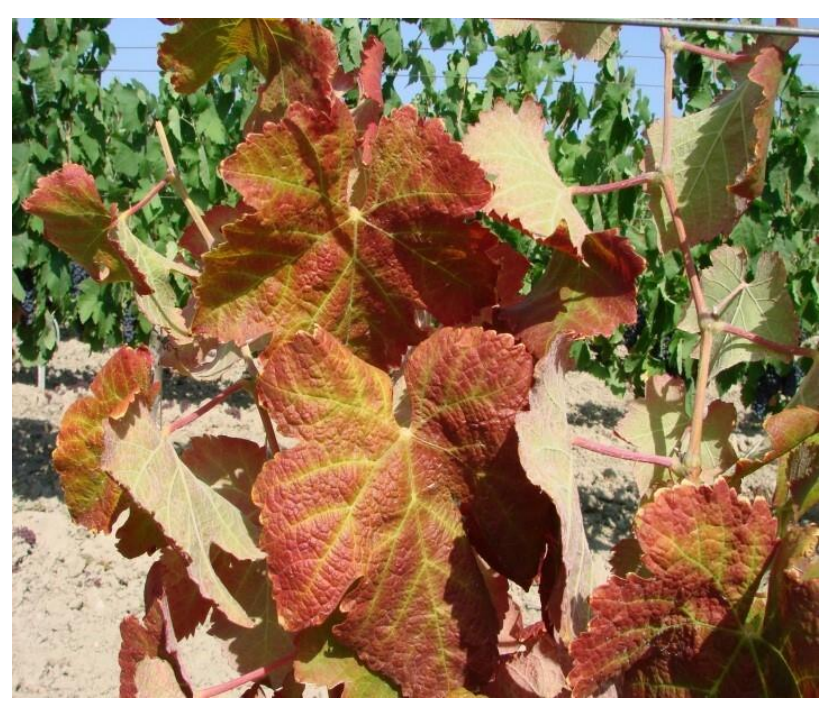

Figure 2 Typical symptom of Grapevine leafrollassociated viruses in red grape varieties. Reddening of foliage but the veins still green (Çanakkale-Bozcaada, Vitis vinifera cv. Syrah)

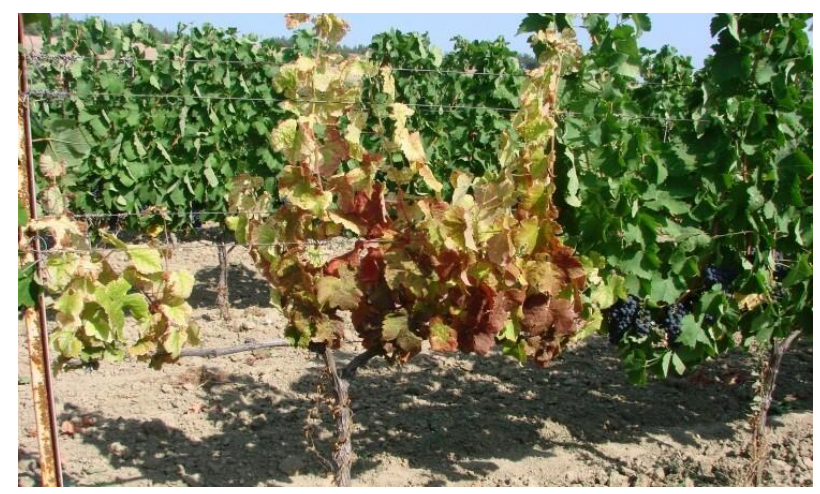

Figure 3 Grapevine canopy infected by Grapevine leafroll-associated virus 4-9 (Manisa-Alaşehir, Vitis vinifera cv. Syrah)

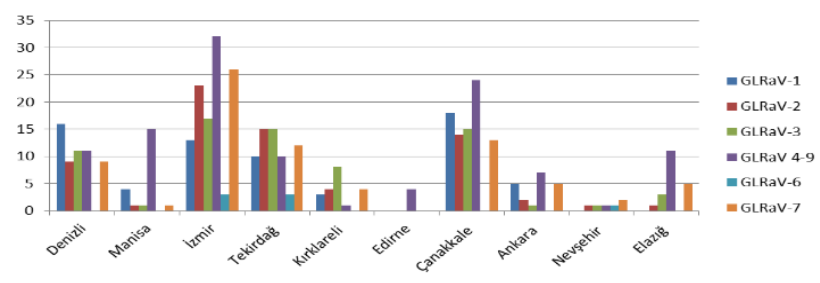

Figure 4 Distribution of Grapevine leafroll-associated viruses in Turkey 
Table 1 Regional distribution and incidence of Grapevine-leafroll associated viruses detected in Turkey

\begin{tabular}{|c|c|c|c|c|c|c|c|c|c|}
\hline \multirow{2}{*}{ Provinces } & \multirow{2}{*}{ TS } & \multicolumn{7}{|c|}{ Viruses Infectivity } & \multirow{2}{*}{ VFS } \\
\hline & & GLRaV-1 & GLRaV-2 & GLRaV-3 & GLRaV 4-9 & GLRaV-6 & GLRaV-7 & Total & \\
\hline \multicolumn{10}{|c|}{ Marmara } \\
\hline Çanakkale & 26 & $18(69.23 \%)$ & $15(57.69 \%)$ & $15(57.69 \%)$ & $24(92.3 \%)$ & - & $12(46.15 \%)$ & & $1(3.84 \%)$ \\
\hline Tekirdağ & 24 & $12(50 \%)$ & $15(62.5 \%)$ & $15(62.5 \%)$ & $10(41.66 \%)$ & $3(12.5 \%)$ & $12(50 \%)$ & & $8(33.33 \%)$ \\
\hline Kirklareli & 17 & $3(17.64 \%)$ & $4(23.53 \%)$ & $8(62.5 \%)$ & $1(5.88 \%)$ & - & $4(23.52 \%)$ & & $9(35.29 \%)$ \\
\hline Edirne & 9 & - & - & - & $4(44.44 \%)$ & - & - & & $5(55.55 \%)$ \\
\hline RT & 76 & $33(43.42 \%)$ & $34(44.74 \%)$ & $38(50 \%)$ & $39(51.32 \%)$ & $3(3.95 \%)$ & $28(36.84 \%)$ & $53(69.74 \%)$ & $23(30.26 \%)$ \\
\hline \multicolumn{10}{|c|}{ Eastern Anatolia } \\
\hline Elazığ & 11 & - & $1(9.09 \%)$ & $3(27.27 \%)$ & $11(100 \%)$ & - & $5(45.45 \%)$ & & - \\
\hline RT & 11 & - & $1(9.09 \%)$ & $3(27.27 \%)$ & $11(100 \%)$ & - & $5(45.45 \%)$ & $11(100 \%)$ & - \\
\hline \multicolumn{10}{|c|}{ Central Anatolia } \\
\hline Ankara & 13 & $5(38.46 \%)$ & $2(15.38 \%)$ & $1(7.69 \%)$ & $7(53.84 \%)$ & - & $5(38.46 \%)$ & & $6(38.46 \%)$ \\
\hline Nevşehir & 21 & - & $1(4.76 \%)$ & $1(4.76 \%)$ & $1(4.76 \%)$ & $1(4.76 \%)$ & $2(9.52 \%)$ & & $19(85.71 \%)$ \\
\hline RT & 34 & $5(14.70 \%)$ & $3(8.82 \%)$ & $2(5.88 \%)$ & $8(23.53 \%)$ & $1(2.94 \%)$ & $8(23.53 \%)$ & $9(26.47 \%)$ & $25(73.53 \%)$ \\
\hline \multicolumn{10}{|c|}{ Aegean } \\
\hline Denizli & 30 & $15(50 \%)$ & $9(30 \%)$ & $12(40 \%)$ & $9(30 \%)$ & - & $9(30 \%)$ & & $12(40 \%)$ \\
\hline İzmir & 35 & $13(37.14 \%)$ & $21(62.5 \%)$ & $17(48.57 \%)$ & $32(91.42 \%)$ & $2(5.71 \%)$ & $27(77.14 \%)$ & & $2(2.85 \%)$ \\
\hline Manisa & 27 & $4(14.81 \%)$ & $1(3.70 \%)$ & $2(7.40 \%)$ & $15(55.55 \%)$ & $1(3.70 \%)$ & - & & $9(29.62 \%)$ \\
\hline RT & 92 & $37(40.22 \%)$ & $31(33.69 \%)$ & $31(33.69 \%)$ & $56(60.87 \%)$ & $3(3.26 \%)$ & $36(39.13 \%)$ & $69(75 \%)$ & $23(25 \%)$ \\
\hline \multicolumn{10}{|c|}{ Total } \\
\hline VB & 213 & $70(32.86 \%)$ & $69(32.39 \%)$ & $74(34.74 \%)$ & $114(53.52 \%)$ & $7(3.28 \%)$ & $77(36.15 \%)$ & & \\
\hline SB & & \multicolumn{7}{|c|}{$143(67.14 \%)$} & $70(32.86 \%)$ \\
\hline
\end{tabular}

TS: Tested sample, VFS: Virus free samples, RT: Regional total, VB: Virus based, SB: Sample based

Table 2 Mixed infections types detected in the survey areas

\begin{tabular}{|c|c|c|c|}
\hline Mix infection type & Detected samples & Mix infection type & Detected samples \\
\hline GLRaV-1 and -3 & $2(2.13 \%)$ & GLRaV-2, -3 and -7 & $5(5.32 \%)$ \\
\hline GLRaV-1 and -9 & $4(4.25 \%)$ & GLRaV-2, -4-9 and -7 & $5(5.32 \%)$ \\
\hline GLRaV-1 and -7 & $1(1.06 \%)$ & GLRaV-3, 4-9 and -7 & $2(2.13 \%)$ \\
\hline GLRaV-2 and -3 & $2(2.13 \%)$ & GLRaV-1, $-2,-3$ and 4-9 & $2(2.13 \%)$ \\
\hline GLRaV-2 and -9 & $2(2.13 \%)$ & GLRaV-1, $-2,-3$ and -7 & $1(1.06 \%)$ \\
\hline GLRaV-3 and 4-9 & $1(1.06 \%)$ & GLRaV-1, $-2,-4-9$ and -7 & $4(4.25 \%)$ \\
\hline GLRaV-4 and -7 & $6(6.38 \%)$ & GLRaV-1, $-3,4-9$ and -7 & $3(3.19 \%)$ \\
\hline GLRaV-1, -2 and -3 & $1(1.06 \%)$ & GLRaV-2, $-3,4-9$ and -7 & $3(3.19 \%)$ \\
\hline GLRaV-1, -2 and $4-9$ & $2(2.13 \%)$ & GLRaV-1, $-2,-3,4-9$ and -7 & $34(36.17 \%)$ \\
\hline GLRaV-1, -3 and 4-9 & $2(2.13 \%)$ & GLRaV-2, $-3,4-9,-6$ and -7 & $4(4.25 \%)$ \\
\hline GLRaV-1, -3 and -7 & $2(2.13 \%)$ & GLRaV-1, $-2,-3,4-9,-6$ and -7 & $3(3.19 \%)$ \\
\hline GLRaV-1, 4-9 and -7 & $3(3.19 \%)$ & & \\
\hline
\end{tabular}

This research revealed that mixed infection of GLRaVs is prevalent in tested grapevines like the other researches (Akbaş et al., 2007; Fiore et al., 2008; Fuchs et al., 2009; Kaya and Erilmez 2014; Liu et al., 2013; Oksal et al., 2018; Önder and Gümüş, 2015). Totally twenty three different kinds of mix infections were detected in this research. The most prevalent virus, GLRaV4-9 constitutes sixteen different types of mix infection with other viruses as shown in Table 2. Furthermore, triple combination of GLRaV4-9 was also detected with GLRaV-1 and -2, GLRaV-1 and -3, GLRaV-1 and -7, GLRaV-2 and -7, and GLRaV-3 and -7. The most widespread mix infection type was GLRaV-1, $2,-3,4-9$ and -7 , with the rate $36.17 \%$ (Table 2 ). On the other hand, grapevines with single infections of GLRaV-1, $-2,-3,4-9$ and -7 were also determined. Additionally, no mixed infected sample was reported in Edirne (Table 3).

Within the collected samples, Merlot and Syrah were the most common cultivars, followed by Cabernet Sauvignon, Chardonnay, Sauvignon Blanc, Alicante Bouschet and Malbec, respectively. As can be seen in the table above, the disease was more widespread in these wine grape varieties than Turkish local varieties, but at least one of GLRaVs were also determined in locals (Boğazkere, Öküzgözü, Tahannebi, Papazkarası, Kalecik Karası,
Malatya Karası and Hacıkıran). All provinces are infected one or more GLRaVs, and Denizli, İzmir, Çanakkale and Tekirdağ provinces demonstrated a great variation in mixed infection pattern, besides single infection was present, especially for GLRaV4-9, in the same locations. However, there was only one multiple infection type in Nevşehir. In İzmir (11/35), Çanakkale (10/26), Tekirdağ (6/24) and Denizli (5/30) the most widespread mixed infection type was GLRaV-1, 2, 3, 4-9 and 7 (Table 3).

Grapevine leafroll disease, which is a significant virus disease in vineyard areas, potentially causing remarkable yield reduction around the world. Viruses that cause this disease lead late ripening of fruits, $25-50 \%$ decrease in sugar content and fruits that are not fully ripened in color (Goheen, 1998). Considering the place and importance of grape production in our country, the presence and spread of these viruses emerge as a serious problem that needs to be addressed.

From past to present, ELISA has been the main method used for diagnosis of GLRaVs in the world. Although ELISA already a widely used method for detecting these viruses, it is useful to support the results of this test with RT-PCR, since low or variable virus titers cannot always be detected by ELISA. Unlike RT-PCR, new molecular 
methods have been used to detect these viruses worldwide. In the first, a multiplex RT-PCR method was evolved, which allows identification of nine grapevine infecting viruses at the same time, GLRaV-1, -2 and -3 are some of them. The results show that RT-PCR is a dependable and prompt method for identifying grapevine infecting viruses in a big amount of samples that can be used instead of ELISA or RT-PCR (Gambino and Gribaudo, 2006). In addition to these methods, qRT-PCR method, which is a quantitative method, was used to detect Grapevine leafroll associated viruses.

Table 3a Distribution of detected GLRaVs in Turkey viticulture areas

\begin{tabular}{|c|c|c|c|}
\hline Province & Grapevine cultivar & Infected/Tested & GLRaVs Infection type (frequency) \\
\hline \multirow{16}{*}{ Denizli } & Sauvignon Blanc & $3 / 5$ & GLRaV-1, -2, -3, 4-9 and -7 (1) \\
\hline & & & GLRaV $-1,-3$ and -7 (1) \\
\hline & & & GLRaV-1 and 4-9 (1) \\
\hline & Sangiovese & $1 / 1$ & GLRaV-1, -2, -3, 4-9 and -7 (1) \\
\hline & Merlot & $1 / 3$ & GLRaV-1 (1) \\
\hline & Syrah & $1 / 4$ & GLRaV-1, -3 and -7 (1) \\
\hline & Cabernet Sauvignon & $1 / 1$ & GLRaV-1, -2 and 4-9 (1) \\
\hline & Alicante Bouschet & $1 / 1$ & GLRaV-1 and 4-9 (1) \\
\hline & Chardonnay & $1 / 2$ & GLRaV-1, -3 and 4-9 (1) \\
\hline & Bogazkere & $1 / 1$ & GLRaV-3 (1) \\
\hline & Unknown & $8 / 12$ & GLRaV-1, -2, -3, 4-9 and -7 (3) \\
\hline & & & GLRaV-1, -2, 4-9 and -7 (1) \\
\hline & & & GLRaV-1, -2 and -3 (1) \\
\hline & & & GLRaV-1, -3 and 4-9 (1) \\
\hline & & & GLRaV-1 and -7 (1) \\
\hline & & & GLRaV-2 (1) \\
\hline \multirow{8}{*}{ Manisa } & Öküzgözü & $1 / 1$ & GLRaV 4-9 (1) \\
\hline & Alicante Bouschet & $2 / 3$ & GLRaV 4-9 (2) \\
\hline & Syrah & $1 / 1$ & GLRaV 4-9 (1) \\
\hline & Chardonnay & $2 / 4$ & GLRaV-1 (1) \\
\hline & & & GLRaV-1, -2, 4-9 and -7 (1) \\
\hline & Unknown & $12 / 18$ & GLRaV 4-9 (9) \\
\hline & & & GLRaV-1 (2) \\
\hline & & & GLRaV-3 and 4-9 (1) \\
\hline \multirow{15}{*}{ İzmir } & Colombart & $2 / 2$ & GLRaV-2, 4-9 and -7 (1) \\
\hline & & & GLRaV-2, $-3,4-9$ and -7 (1) \\
\hline & Chardonnay & $2 / 2$ & GLRaV-2, $-3,4-9$ and -7 (1) \\
\hline & & & GLRaV-2, $-3,4-9,-6$ and -7 (1) \\
\hline & Syrah & $2 / 2$ & GLRaV-2, 4-9 and -7 (1) \\
\hline & & & GLRaV-2 and 4-9 (1) \\
\hline & Sauvignon Blanc & $1 / 1$ & GLRaV 4-9 and -7 (1) \\
\hline & Merlot & $1 / 1$ & GLRaV-2, 4-9 and -7 (1) \\
\hline & Unknown & $25 / 27$ & GLRaV 4-9 (6) \\
\hline & & & GLRaV 4-9 and -7 (2) \\
\hline & & & GLRaV-2, 4-9 and -7 (2) \\
\hline & & & GLRaV-1, 4-9 and -7 (1) \\
\hline & & & GLRaV-1, $-2,-3$ and -7 (1) \\
\hline & & & GLRaV-2, $-3,4-9,-6$ and -7 (2) \\
\hline & & & GLRaV-1, $-2,-3,4-9$ and -7 (11) \\
\hline \multirow{14}{*}{ Çanakkale } & Syrah & $4 / 4$ & GLRaV 4-9 (2) \\
\hline & & & GLRaV-1 and 4-9 (1) \\
\hline & & & GLRaV-1, $-2,-3,4-9$ and -7 (1) \\
\hline & Merlot & $2 / 2$ & GLRaV-1, -2, -3, 4-9 and -7 (2) \\
\hline & Cabernet Sauvignon & $2 / 2$ & GLRaV-1, $-2,-3$ and $4-9$ (1) \\
\hline & & & GLRaV-1, -2, -3, 4-9 and -7 (1) \\
\hline & Unknown & $17 / 18$ & GLRaV 4-9 (4) \\
\hline & & & GLRaV-1 and -3 (1) \\
\hline & & & GLRaV-2 and 4-9 (1) \\
\hline & & & GLRaV-1, -2 and 4-9 (1) \\
\hline & & & GLRaV-1, $-2,4-9$ and -7 (1) \\
\hline & & & GLRaV-1, -3, 4-9 and -7 (3) \\
\hline & & & GLRaV-1, $-2,-3$ and $4-9$ (1) \\
\hline & & & GLRaV-1, $-2,-3,4-9$ and -7 (5) \\
\hline \multirow{7}{*}{ Kirklareli } & Cabernet Sauvignon & $1 / 5$ & GLRaV-3 (1) \\
\hline & Merlot & $5 / 8$ & GLRaV-3 (1) \\
\hline & & & GLRaV-1 and -3 (1) \\
\hline & & & GLRaV-2, -3 and -7 (3) \\
\hline & Malbec & $3 / 4$ & GLRaV-1 (1) \\
\hline & & $3 / 4$ & GLRaV-3 (1) \\
\hline & & & GLRaV-1, -2, -3, 4-9 and -7 (1) \\
\hline
\end{tabular}


Table 3b Distribution of detected GLRaVs in Turkey viticulture areas

\begin{tabular}{|c|c|c|c|}
\hline Province & Grapevine cultivar & Infected/Tested & GLRaVs Infection type (frequency) \\
\hline \multirow{14}{*}{ Tekirdağ } & Merlot & $3 / 3$ & GLRaV-2 (1) \\
\hline & & & GLRaV-1, -2, -3, 4-9 and -7 (1) \\
\hline & & & GLRaV-1, $-2,-3,4-9,-6$ and -7 (1) \\
\hline & Cabernet Sauvignon & $1 / 3$ & GLRaV-1, -2, -3, 4-9 and -7 (1) \\
\hline & Syrah & $4 / 5$ & GLRaV-3 (1) \\
\hline & & & GLRaV-2 and -3 (1) \\
\hline & & & GLRaV-2, -3 and -7 (2) \\
\hline & Chardonnay & $2 / 5$ & GLRaV-2 and -3 (1) \\
\hline & & & GLRaV-1, -2, -3, 4-9 and -7 (1) \\
\hline & Pinot Noir & $3 / 3$ & GLRaV-1, -2, -3, 4-9 and -7 (2) \\
\hline & & & GLRaV-1, $-2,-3,4-9,-6$ and -7 (1) \\
\hline & Gamay & $1 / 1$ & GLRaV-1, $-2,-3,4-9$ and -7 (1) \\
\hline & Papazkarası & $1 / 1$ & GLRaV-1, -2, -3, 4-9 and -7 (1) \\
\hline & Others & $1 / 3$ & GLRaV $-1,-2,-3,4-9,-6$ and -7 (1) \\
\hline \multirow{3}{*}{ Edirne } & Cabernet Sauvignon & $2 / 3$ & GLRaV 4-9 (2) \\
\hline & Syrah & $1 / 1$ & GLRaV 4-9 (1) \\
\hline & Unknown & $1 / 5$ & GLRaV 4-9 (1) \\
\hline \multirow{8}{*}{ Ankara } & Kalecik Karası & $2 / 3$ & GLRaV-1, 4-9 and -7 (1) \\
\hline & & & GLRaV-1, -2, -3, 4-9 and -7 (1) \\
\hline & Alicante Bouschet & $1 / 1$ & GLRaV-1 and 4-9 (1) \\
\hline & Sauvignon Blanc & $1 / 1$ & GLRaV 4-9 (1) \\
\hline & Unknown & $3 / 5$ & GLRaV 4-9 and -7 (1) \\
\hline & & & GLRaV-1, 4-9 and -7 (1) \\
\hline & & & GLRaV-1, -2, 4-9 and -7 (1) \\
\hline & Others & $0 / 3$ & - \\
\hline \multirow{3}{*}{ Nevşehir } & Ürgüp Siyahı & $0 / 1$ & - \\
\hline & Unknown & $2 / 20$ & GLRaV-7 (1) \\
\hline & & & GLRaV-2, $-3,4-9,-6$ and -7 (1) \\
\hline \multirow{7}{*}{ Elazı̆g } & Tahannebi & $1 / 1$ & GLRaV-3, 4-9 and -7 (1) \\
\hline & Malatya Karasi & $1 / 1$ & GLRaV 4-9 and -7 (1) \\
\hline & Hacıkıran & $1 / 1$ & GLRaV 4-9 (1) \\
\hline & Unknown & $8 / 8$ & GLRaV 4-9 (5) \\
\hline & & & GLRaV 4-9 and -7 (1) \\
\hline & & & GLRaV-3, 4-9 and -7 (1) \\
\hline & & & GLRaV-2, $-3,4-9$ and -7 (1) \\
\hline
\end{tabular}

In the present study, occurrence of leafroll infection was detected at a rate of $67.14 \%$ in Turkey. GLRaV4-9 was detected as the most prevalent leafroll associated virus with the rate of $53.52 \%$, followed by GLRaV-7 (36.15\%). This record was new for the world, because many researches related the topic revealed that the most common viruses leading GLD was GLRaV-1 and -3 worldwide (Dida et al., 2012; Gugerli, 2003; Martin et al., 2005; Vončina et al., 2011). Furthermore, other studies in Central Anatolia and Thrace part of Marmara Region showed that the most common viruses causes leafroll were GLRaV-1 and -3 (Akbaş et al., 2007; Çı̆̆şar et al., 2002; Köklü et al., 1998; Y1lmaz et al., 1997), while in our study GLRaV4-9 and GLRaV-7 is the most prevalent in Central Anatolia and GLRaV-3 and GLRaV-2 is the most widespread viruses causing disease in Thrace (Tekirdağ, Kırklareli, Edirne) part of Marmara Region. In a study carried out in various provinces of the Southeastern Anatolia Region (Şanlıurfa, Mardin, Diyarbakır, Adıyaman, Elazı̆̆ Siirt, Malatya) GLRaV-1 was determined to be the most dominant pathogen, followed by GLRaV-3 (Ç1̧̆şar et al., 2000), while in our research for the same region (Elazığ) GLRaV 4-9 was found to be the most prevalent virus, followed by GLRaV-7. Likewise, in another report GLRaV-1 was found to be the most common virus followed by GLRaV-3 among samples collected during September-November in Malatya province, located in the same region, whereas GLRaV4-9 was rarely detected (Oksal et al., 2018). In a research carried out during autumn in Aegean Vineyards (İzmir, Manisa, Denizli, Çanakkale) GLRaV-3 was detected as the most prevalent virus (Kaya and Erilmez 2014), while we found it to be GLRaV 4-9. In a different study conducted in the same region (İzmir, Manisa, Denizli, Aydın, Uşak) using qRT-PCR besides DASELISA, interestingly GLRaV-1 was detected very few unlike our research (Önder and Gümüş, 2015). Elçi (2018) carried out a research during autumn collecting the leaf samples of grapevine to investigate the prevalence of GLRaV-1 besides its genetic diversity and recombination events in two distant region (Hatay, Gaziantep and Tekirdağ), and the virus was detected in all locations with almost same level. However, we found GLRaV-1 at nearly the same rate in Tekirdağ, while in the other province (Elazığ) located in southeastern part of Turkey the virus was not detected. Because of the presence of insect vectors and the wide interchange of propagating materials worldwide, GLRaV-3 is the most prevalent GLRaV within the viticulture areas compared to other leafroll associated viruses. Therefore, vector management is the main control method in preventing spread of the relevant viruses, especially GLRaV-3 (Maree et al., 2013). In our survey, no study was carried out on the vectors of viruses in the field and no mealybug and soft scale individuals were observed on vine samples collected.

Grapevine leafroll disease constitutes a problem not only in our country but also in other parts of the world, thus 
there are various kind of international studies related the causal agents. In the research conducted in the warmer regions of Czech Republic to investigate presence of the sixteen different grapevine infecting viruses including GLRaV-1, -2, -3, -5, -6 and -7, according to DAS-ELISA results GLRaV-1 found to be the most prevalent virus, whereas we detected it as the third most common one (Komínek, 2008). In another study carried out during autumn (April, May, June) in Chile, GLRaV-2 was determined as the most widespread virus among GLRaV$1,-2,-3$ and -7 , after serogically testing confirmed by RTPCR resulting more positive isolates, while in our research the relevant virus was ranked to be the forth (Fiore et al., 2008). In Mendoza, Argentina three leafroll viruses (GLRaV-1, -2 and -3) were investigated in the samples collected from the cultivars of Cabernet Sauvignon, Cabernet Franc and Sauvignon Blanc between April and July, then GLRaV-2 was found to be the most prevalent, while only a few infected samples reported for GLRaV-1 and GLRaV-3 (Lanza Volpe et al. 2010). In the study conducted in Egypt (Ahmed et al., 2004), GLRaV-2 was detected as the most common virus according to DASELISA, whereas GLRaV-1 and GLRaV-3 were only sporadically determined, which is unusual regarding the results obtained before in the other researches (Dida et al., 2012; Gugerli, 2003; Liu et al., 2013; Martin et al., 2005; Vončina et al., 2011). In the study conducted in Tunisian table grape vineyards, GLRaV-3 was determined as the most widespread virus followed by GLRaV-5, -6, -1, -2, and -7 and, GLRaV-3+GLRaV-5 was reported as the most common mixed infection type (Mahfoudhi et al., 2008). However, unlike our research in the five studies indicated above, phloem scrapings from dormant mature canes were used for detection of the viruses instead of fresh leaf tissue. During the study carried out from the late August through early October in New York, USA leaf samples were used for extraction just like our study and GLRaV-3 was found to be the most widespread virus following by GLRaV-1 and GLRaV-2, respectively and the most common multiple infection is GLRaV-1 + GLRaV-3 (Fuchs et al., 2009). In a similar manner, in Oregon and Washington, USA, GLRaV-3 was reported as the most prevalent virus, followed by GLRaV-1 and -2 (Martin et al., 2005). In another study conducted Virginia, USA from between lateJune and late-August, only for two GLRaVs were investigated, so that GLRaV-3 was found to be the most common virus after GLRaV-2 (Jones et al., 2015). In another research conducted between late August and October throughout a wide survey area of China, collected petiole samples were tested by RT- PCR and SG qRTPCR, and GLRaV-3 was determined in all tested samples, followed by GLRaV-1, -2, and -4, and the most widespread mixed infection type was found GLRaV-1 and -3 (Liu et al., 2013). Consequently, comparing with the international studies mentioned above, our findings was quite different, for instance the most widespread multiple infection is GLRaV-1, -2, -3, -4 and -7 instead of GLRaV-1 and -3.

\section{Conclusion}

Consequently, with this study totally 213 grapevine samples taken from İzmir, Manisa, Denizli, Çanakkale, Tekirdağ, Edirne, Kırklareli, Elazı̆̆g, Nevşehir and Ankara which are important viticulture areas of Turkey were tested by ELISA and 143 of them $(67.14 \%)$ were found to be infected with one or more GLRaVs. In this research, GLRaV-1, -2, -3, 4-9 and -7 were reported as remarkable viruses infecting grapevine in the country. The existence of these viruses in the mentioned provinces may cause important problems in terms of grape production and export in the future unless the necessary precautions are taken to prevent the infection. For this reason, it should be ensured that the propagating material, which plays a significant role in spreading viral agent, is virus free and necessary precautions should be taken in nurseries. After all, the prevalent occurrence of leafroll viruses can be explained by the careless use of infected plant material for propagating by the producers. In addition, management with mealybugs and soft scale insects which are vectors of the agent is essential. As a conclusion, the data obtained from this research could be useful for the enhancement of integrated management practices in order to reduce the virus infection damage in grapevine.

\section{Acknowledgement}

This research was supported by the Project coded 1090005 funding by The Scientific and Technological Research Council of Turkey (Tubitak).

\section{References}

Ahmed HMH, Digiaro M, Martelli GP. 2004. Viruses and virus diseases of grapevine in Egypt. Bulletin OEPP/EPPO Bulletin, 34: 395-398. Available from: https://doi.org /10.1111/j.1365-2338.2004.00759.x

Akbaş B, Kunter B, İlhan D. 2007. Occurrence and distribution of grapevine leafroll-associated viruses $1,2,3$ and 7 in Turkey. Journal of Phytopathology, 155: 122-124. Available from: https://doi.org/10.1111/j.1439-0434.2007.01206.x

Anonymous. 2017. Food and Agricultural Commodities Production, Commodities by Country. Available from: http://www.fao.org/faostat/en/\#data/QC [Accessed 01.06.2019]

Besse S, Gugerli P. 2009. Development and characterization of monoclonal antibodies to Grapevine leafroll-associated virus 4 and 5. Abstract RVV. Aussois, France, 18-22 January 2009. pp: 48.

Clark MF, Adams AN. 1977. Charecteristics of the microplate of enzyme-linked immunosorbent assay for the detection of plant viruses. Journal of General Virology., 34: 475-483. DOI: 10.1099/0022-1317-34-3-475; PMID: 323416;

Çiğşar I, Digiaro M, Martelli GG. 2002. Sanitary status of grapevines in south-eastern and central Anatolia Turkey. Bulletin OEPP, 32: 471-475. Available from: https://doi.org/10.1046/j.1365-2338.2002.00591.x [Accessed 01.06.2019]

Çiğşar I, Yılmaz MA. 2000. Detection of grapevine viruses by serological methods in south-east of Turkey. 13th Meeting of the ICVG. Adelaide, Australia, March 12-17, 2000. pp: 143.

Dida L, Elbeaino T, Frasheri D, Digiaro M. 2012. Viruses of grapevine in Kosovo. Phytopathologia Mediterranea, 51(1): 85-90. Available from: http://dx.doi.org/10.14601 /Phytopathol_Mediterr-9478

Elçi, E. 2018. Genomic Variability and Recombination Analysis of Grapevine leafroll-associated virus-1 Isolates from Turkey. Tarım Bilimleri Dergisi/Journal of Agricultural Sciences, 25: 319-327. Available from: https://doi.org /10.15832/ankutbd.402162 
Fiore N, Prodán S, Montealegre J, Aballay E, Pino AM, Zamorano A. 2008. Survey of grapevine viruses in Chile. Journal of Plant Pathology, 90: 125-130. Available from: http://repositorio.uchile.cl/handle/2250/120121

Fuchs M, Martinson TE, Loeb GM, Hoch HC. 2009. Survey for the three major leafroll disease-associated viruses in Finger Lakes vineyards in New York. Plant Disease., 93: 395-401. DOI: 10.1094/PDIS-93-4-0395; PMID: 30764222;

Gambino G, Gribaudo I. 2006. Simultaneous detection of nine grapevine viruses by multiplex reverse transcriptionpolymerase chain reaction with coamplification of a plant RNA as internal control. Phytopathology., 96: 1223-1229. DOI: 10.1094/PHYTO-96-1223; PMID: 18943959;

Goheen AC. 1998. Leafroll. In: (Pearson RC, Goheen AC). Compendium of Grape Diseases. St. Paul, MN:. APS. pp: 52. 08905408889780890540886.

Gugerli P. 2003. Grapevine leafroll and related viruses. Proc 14th Meeting ICVG. Locorotondo (Bari), Italy, September 12-17, 2003. pp: 25-31.

Jones TJ, Rayapati NA, Nita M. 2015. Occurrence of Grapevine leafroll associated virus-2, -3 and Grapevine fleck virus in Virginia, U.S.A., and factors affecting virus infected vines. Eur. J. Plant Pathol., 142: 209-222. Available from: http://dx.doi.org/10.1007/s10658-015-0605-z

Kaya A, Erilmez S. 2014. Detection of Viruses in Aegean Region Grapevines. J. Turk. Phytopath., 43: 45-57. Available from: http://www.fitopatoloji.org.tr/arsiv/2014/2014-1-3-45-57.pdf [Accessed 04.10.2019]

Komínek P. 2008. Distribution of grapevine viruses in vineyards of the Czech Republic. Journal of Plant Pathology, 90(2): 357-358. Available from: http://dx.doi.org/10.4454 /jpp.v90i2.673

Köklü G, Digiaro M, Savino V. 1998. A survey of grapevine viruses in Turkish Thrace. Phytopathologia Mediterranea, 37(3): 140-142. Available from: https://www.jstor.org /stable/i40100545

Lanza Volpe M, Gómez Talquenca S, Engel EA, Gracia O. 2010. Incidence of grapevine leafroll associated viruses $-1,-2$, and -3 in Mendoza vineyards. Tropical Plant Pathology, 35: $377-$ 380. Available from: http://dx.doi.org/10.1590/S198256762010000600007

Liu MH, Li MJ, Qi HH, Guo R, Liu XM, Wang Q, Cheng YQ. 2013. Occurrence of Grapevine leafroll-associated viruses in China. Plant Disease., 97: 1339-1345. DOI: 10.1094/PDIS01-13-0048-RE; PMID: 30722147;

Mahfoudhi N, Digiaro M, Dhouibi MH. 2008. Incidence and distribution of Grapevine leafroll-associated viruses in Tunisian Vineyards. JPhytopathology, Available from: 156: 556-558. https://doi.org/10.1111/j.1439-0434.2008.01414.x

Maree HJ, Almeida RPP, Rachelle B, Chooi KM, Cohen D, Dolja VV, Fuchs MF, Golino DA, Jooste AEC, Martelli GP, Naidu RA, Rowhani A, Salderelli P, Burger JT. 2013. Grapevine leafroll-associated virus-3. Front. Microbiol., 4: 1-21. Available from: https://doi.org/10.3389/fmicb.2013.00082
Martelli GP, Abou Ghanem-Sabanadzovic N, Agranowsky AA, Al Rwahnih M, Dolja VV, Dovas CI, Fuchs M, Gugerli P, Hu JS, Jelkmann W, Katis NI, Maliogka VI, Melzer MJ, Menzel W, Minafra A, Rott ME, Rowhani A, Sabanadzovic S, Salderelli P. 2012. Taxonomic revision of the family Closteroviridae with special reference to the grapevine leafroll-associated member of the genus Ampelovirus and the putative species unassigned to the family. Journal of Plant Pathology., 94: 7-19. Available from: http://dx.doi.org/10.4454/jpp.fa.2012.022

Martin RR, Eastwell KC, Wagner, A, Lamprecht S, Tzanetakis IE. 2005. Survey for viruses of grapevine in Oregon and Washington. Plant Disease., 89: 763-766. Available from: https://doi.org/10.1094/PD-89-0763 [Accessed 01.06.2019]

Naidu RA, Rowhani A, Fuchs M, Golino D, Martelli GP. 2014. Grapevine leafroll: A complex viral disease affecting a highvalue fruit crop. Plant Disease., 98: 1172-1185. DOI: 10.1094/PDIS-08-13-0880-FE; PMID: 30699617;

Oksal HD, Aydın S, Sipahioğlu HM. 2018. Survey for Grapevine leafroll viruses (GLRaVs) in Malatya region. Bitki Koruma Bülteni / Plant Protection Bulletin, 58: 215-220. Available from: https://doi.org/10.16955/bitkorb.430912

Önder S, Gümüş M. 2015. Occurrence of Grapevine leafrollassociated viruses (GLRaVs) in Aegean Vineyards, Turkey. Proceedings of $18^{\text {th }}$ Congress of ICGV, Ankara, Turkey, 7-11 September 2015. pp: 44-45.

Reynard JS, Schneeberger PH, Frey JE, Schaerer S. 2015. Biological, Serological, and Molecular Characterization of a Highly Divergent Strain of Grapevine leafroll-associated virus 4 Causing Grapevine Leafroll Disease. Phytopathology., 105 (9): 1262-1269. Available from: https://doi.org/10.1094/PHYTO-12-14-0386-R

Söylemezoğlu G, Kunter B, Akkurt M, Sağlam M, Ünal A, Buzrul S, Tahmaz H. 2015. Bağcılığın Geliştirilmesi Yöntemleri ve Üretim Hedefleri. Ziraat Mühendisliği 8 . Teknik Kongresi. Ankara, Turkey, January 12-16, 2015. pp: 606-629.

Tsai CW, Rowhani A, Golino DA, Daane KM, Almeida RP. 2010. Mealybug transmission of grapevine leafroll viruses: An analysis of virus-vector specificity. Phytopathology., 100: 830-834. DOI: 10.1094/PHYTO-100-8-0830; PMID: 20626287;

Vončina D, Badurina D, Preiner D, Cvjetkovic B, Maletic E, Karaoglan Kontic J. 2011. Incidence of virus infections in grapevines from Croatian collection plantations. Phytopathologia Mediterranea., 50(2): 316-326. Available from: http://dx.doi.org/10.14601/Phytopathol_Mediterr-8641 [Accessed 01.06.2019]

Yılmaz MA, Yurtmen M, Çiğşar I, Özaslan M. 1997. Survey of grapevine viruses in Turkey. Proc 12th Meeting ICVG. Lisbon, Portugal, $28^{\text {th }}$ September-2 ${ }^{\text {nd }}$ October 1997. pp: 113. 